\title{
Studies on bioactive components retention in sugar based amla products
}

\author{
- K.P. Sivakumar ${ }^{1 *}$ and B. Nallakurumban ${ }^{2}$
}

${ }^{1}$ Krishi Vigyan Kendra (TNAU), Virinjipuram, Vellore (T. N.) India

${ }^{22}$ Department of Family Resource Management, Home Science College and Research Institute (TNAU), Madurai (T. N.) India Email: drsiva77@rediffmail.com)

*Author for Correspondence

Research chronicle : Received : 10.08.2020; Revised : 27.09.2020; Accepted : 25.11.2020

\section{SUMMARY :}

Amla fruit is known for its antioxidant activity (Vitamin C) and medicinal properties. Value added products make the fruit available throughout the year and helps to promote the use of amla among the public. Hence an attempt was made to standardized sweet based products viz.,jam, squash and jelly with different treatments. The prepared amla products were standardized on the basis of sensory evaluation. The bio active components and sensory evaluation of amla products were analysed during storage period. The shelflife studies of amla jam, squash and jelly were also done at room temperature and it has more shelflife with high organoleptic scores.

KEY WORDS : Amla products, Bio active components, Sensory evaluation and Sugars

How to cite this paper : Sivakumar, K.P. and Nallakurumban, B. (2020). Studies on bioactive components retention in sugar based amla products. Internat. J. Proc. \& Post Harvest Technol., 11(2) : 39-45. DOI: 10. 15740/HAS/IJPPHT/11.2/39-45. Copyright@2020: Hind Agri-Horticultural Society. 